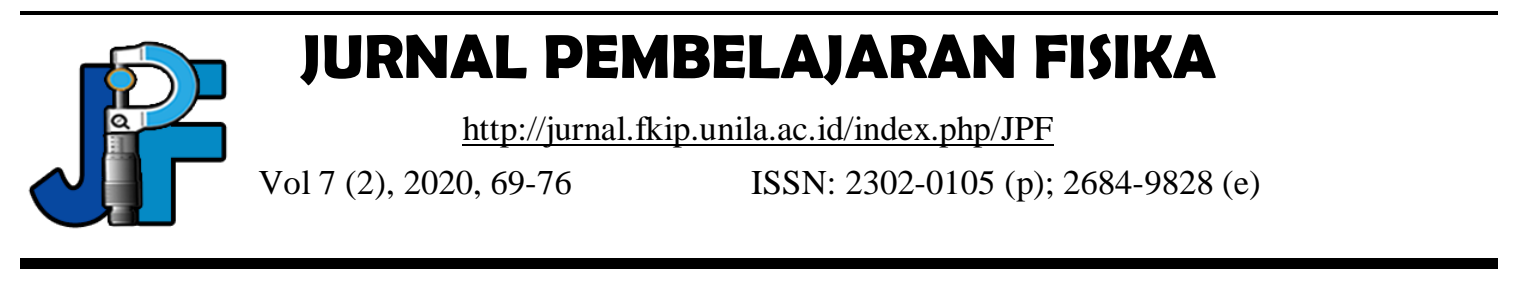

\title{
The Effectiveness of Puzzle as Solar System Learning Media for Children with Disabilities
}

\author{
Wahyuni Fajar Arum ${ }^{1 *}$, Erwan Eko Prasetiyo ${ }^{2}$,Farah Putri Wenang Lusianingrum ${ }^{3}$ \\ ${ }^{1}$ Sekolah Tinggi Teknologi Kedirgantaraan, Yogyakarta, Indonesia \\ ${ }^{2}$ Sekolah Tinggi Teknologi Kedirgantaraan, Yogyakarta, Indonesia \\ ${ }^{3}$ Universitas Sultan Ageng Tirtayasa, Indonesia \\ *e-mail: wahyunifajararum@gmail.com
}

\begin{abstract}
Puzzle games are very suitable for children with disabilities for the learning process because with puzzle games they will get knowledge by processing the information as a visual learner. The purpose of this research is to find out the effectiveness of puzzle games in the learning process about the solar system for children with disabilities. This research is a type of RnD type. The research design used in this study is quantitative and qualitative. This research is used tests, observations, documentation, \& interviews for data collection. The results of this study show that the use of solar system learning media in the form of puzzles has effectiveness which affects the process of solar system learning, this can be seen from the pre-test and post-test scores. The average of pre-test scores before the learning process using puzzles is 14.29 while the post-test scores after is 42.89 thus, it can be concluded that there is an increase in the mean value of 28.57.
\end{abstract}

Keywords: disabilities, puzzle, physics, effectiveness

DOI: http://dx.doi.org/10.23960/jpf.v7.n2.202003 


\section{INTRODUCTION}

Everyone has rights and obligations, one of which is in terms of education. This has already been stated in the 1945 Constitution article 31 part 1 which states that "Every citizen has the right for education". Based on this verse, it can be concluded that education does not look at any race, class or religion. In any condition and situation, everyone has the right for education, including children with disabilities.

In its realization, children with disabilities are very vulnerable to get discriminated in obtaining the rights they have, especially their right for education. This is caused by several things such as due to inequality in physical or psychological conditions with children in general (Afifah, 2014).

Physic is one of science that studies about materials, energy and natural phenomena or events, both microscopic and macroscopic and also about the energy and matter changes. Physic is a subject of natural science which related to calculations and formulas. So far, physic is the most avoided subject by students because it seems difficult and complicated due to various kinds of problems within it.

Solar system is one of the learning materials in physics. Solar system is one of the most complicated learning materials in physic due to its discussion about all planets in the solar system and also its satellites along with other space objects such as meteors, comets, asteroids and others. In general, this material is taught in school with the use of textbooks which contain about the solar system and its theory. In fact the solar system material will be more attractive and easier to understand when using an interesting learning media (Fauzan, 2017).

Along with the development of science and technology, innovation is needed in the world of education. One of it is the development in learning technology. This is needed so that the concept of physics can be easily understood by developing the educational technology that can overcome problems related to physics. One of the developments in educational technology in learning physics is the making of learning media (Agustina, 2017).

Puzzle is one of learning media in the form of a construction game which is played by putting boxes that have image patterns or shapes so that when it is arranged it will form a certain desired pattern (Putri, 2014). Puzzle is a game that is beneficial to sharpen the brain, train the eyes coordination, hands and logic also increasing patience and knowledge. Puzzles are created with the aim that the children who play it can focus while arranging the puzzles. Another advantaged in puzzle games is that it can help children increasing creativity, recognizing colors and shapes, practicing problem solving and practicing perseverance and attention. Puzzle games are very suitable for children with disabilities in learning process because they can get knowledge by processing information as visual learner.

Based on the importance of education equality for all humans, including children with disabilities in getting knowledge for the sake of life prosperity thus, this study was conducted to determine the effectiveness of learning media in the form of puzzles as solar system learning media for children with disabilities. 


\section{METHOD}

\section{Research Design \& Procedures}

This research is a type of research and development. The research design used in this study is quantitative and qualitative. The research phases include information gathering, planning, product development, validation and test, then research. The study was conducted at Sayap Ibu Foundation Nursing Home 2 located at Kalasan, Sleman, Yogyakarta on June $26^{\text {th }}-$ July $2^{\text {nd }}, 2019$.

\section{Population and Sample}

The study population for this research were children with disabilities in the Sayap Ibu Nursing Home. This research used sample techniques with purposive sampling area with the number of sampling used in the research are 7 children with disabilities from Sayap Ibu Foundation Nursing Home.

Sayap Ibu Nursing Home in Yogyakarta has three institutions that have different locations and functions from one another. The Nursing Home 1 is used for nursing neglected toddlers, the Nursing Home 2 and 3 are used as a place for nursing children with multiple disabilities. The research sample was taken from the Sayap Ibu Nursing Home is located at Kadirojo Village, Purwomartani, Kalasan, Sleman, Yogyakarta. In the Nursing Home 2 there are 27 children with multiple disabilities.

\section{Data Collection and Instrument}

Data collection methods used in this study were tests, questionnaires, observation, documentation and also interviews. The tests method conducted were written pre-test and post-test with the tests in the form of matching questions with answers. This kind of test was chosen to make it easier for the children with disabilities to work on the tests.

The observation and documentation methods were conducted to the activities of children with disabilities as well as for collecting questionnaire data on response to the effectiveness of learning media that were filled by the caregivers of children with disabilities in Sayap Ibu Foundation Nursing Home 2.

\section{Data Analysis}

The data analysis techniques used in this research were including planning, implementing, evaluating, composing reports. Planning was conducted in some stages of activity those are determining research samples and instruments used for research in the form of questionnaire. The implementation was carried out by the learning process of solar system materials to the children with disabilities also testing, analyzing and determining the research instruments used. Evaluation was done by analyzing and processing the data that had been collected by test, observation, documentation and interviews method. The report composition was conducted by compiling and reporting the research results. 


\section{RESULT AND DISCUSSION}

The study was conducted at Sayap Ibu Nursing Home 2. The research process was carried out using puzzle as the learning media made from environmental friendly materials that are designed as attractive as possible so it can be used in learning process of solar system material for the children with disabilities.

The solar system material used in this research is related to the description of the shape and the size of earth, moon and sun. The learning process conducted in the research was purposed so that the children with disabilities could get a better view about the simple solar system. The puzzle used in the learning process was made with attractive drawings and writing so that children with disability are interested in playing and learning using the puzzle.
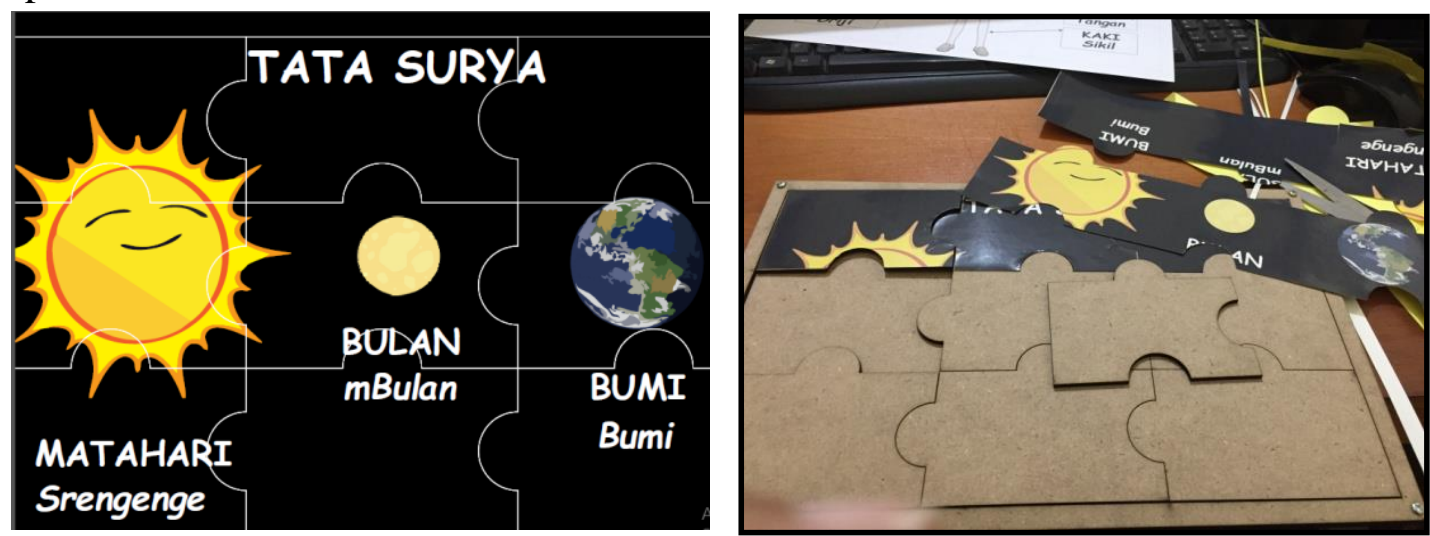

Gambar 1. (a) Puzzle design for solar system material (b) The process of puzzle making as media for solar system material

The data collection in the form of questionnaire was conducted for the caregivers of the disabled children in the Sayap Ibu Nursing Home 2. This questionnaire was used to know the response from the use of learning media in solar system learning. The questionnaire contains questions about the compatibility of media content with the learning objectives, then the learning media to be operated, the influence of learning media in increasing motivation, the influence of learning media in understanding concepts correctly and to arouse new desires and interests The questionnaire results about the effectiveness of the use of puzzle as learning media which is used in the solar system learning for children with disabilities is shown in table 1.

Table 1. The questioner response of the use of puzzle learning media

\begin{tabular}{ccccccc}
\hline Resp. No. & \multicolumn{5}{c}{ Questioner number } & Total \\
\cline { 2 - 6 } & $\mathbf{1}$ & $\mathbf{2}$ & $\mathbf{3}$ & $\mathbf{4}$ & $\mathbf{5}$ & Score \\
\hline 1 & 4 & 4 & 5 & 5 & 5 & 23 \\
2 & 5 & 3 & 4 & 3 & 3 & 18 \\
3 & 4 & 5 & 4 & 5 & 4 & 22 \\
4 & 4 & 3 & 5 & 4 & 5 & 21 \\
5 & 5 & 4 & 4 & 3 & 5 & 21 \\
6 & 5 & 5 & 3 & 5 & 4 & 22 \\
7 & 5 & 3 & 5 & 4 & 3 & 20 \\
\hline
\end{tabular}


Respondents from table 1 are the caregivers of disabled children in Sayap Ibu Nursing Home 2. The caregivers will accompany the children throughout the learning process. Based on data from table 1 it can be stated that the majority of the results of the questionnaire gained the results of answers with scores 4 and 5 which indicate that respondents are agree and strongly agree with the effectiveness of puzzle as a learning media on the learning process of solar system material for children with disabilities. Value 1 represents that the respondent strongly disagrees with the statement on the questionnaire, value 2 represents that the respondent disagrees with the statement on the questionnaire, value 3 represents that the respondent is doubtful about the statement on the questionnaire, value 4 represents that the respondent agrees with the statement on the questionnaire, while value 5 represents that the respondent strongly agree to the statement on the questionnaire.

Tabel 2. Analysis results Bivariate Pearson Correlations

\begin{tabular}{|c|c|c|c|c|c|c|}
\hline & $\mathbf{x . 1}$ & $\mathbf{x . 2}$ & $\mathbf{x . 3}$ & $\mathbf{x . 4}$ & x.5 & $\mathbf{T}$ \\
\hline Pearson Correlation & 1 & -.149 & -.471 & .175 & .176 & $\left..673^{*}\right)$ \\
\hline Sig. (1-tailed) & & .375 & .143 & .103 & .103 & .089 \\
\hline $\mathrm{N}$ & 7 & 7 & 7 & 7 & 7 & 7 \\
\hline Pearson Correlation & -.149 & 1 & -.665 & .647 & .235 & $\left..6811^{*}\right)$ \\
\hline Sig. (1-tailed) & .375 & & .052 & .058 & .306 & .046 \\
\hline $\mathrm{N}$ & 7 & 7 & 7 & 7 & 7 & 7 \\
\hline Pearson Correlation & -.471 & -.665 & 1 & -.070 & .175 & $\left..7811^{*}\right)$ \\
\hline Sig. (1-tailed) & .143 & .052 & & .441 & .354 & .500 \\
\hline $\mathrm{N}$ & 7 & 7 & 7 & 7 & 7 & 7 \\
\hline Pearson Correlation & -.545 & .647 & -.070 & 1 & .176 & $.794\left(^{*}\right)$ \\
\hline Sig. (1-tailed) & .103 & .058 & .441 & & .353 & .016 \\
\hline $\mathrm{N}$ & 7 & 7 & 7 & 7 & 7 & 7 \\
\hline Pearson Correlation & -.545 & .235 & .175 & .176 & 1 & $\left..6811^{*}\right)$ \\
\hline Sig. (1-tailed) & .103 & .306 & .354 & .353 & & .046 \\
\hline $\mathrm{N}$ & 7 & 7 & 7 & 7 & 7 & 7 \\
\hline Pearson Correlation & -.573 & $.681\left(^{*}\right)$ & .000 & $.794\left(^{*}\right)$ & $.681\left(^{*}\right)$ & 1 \\
\hline Sig. (1-tailed) & .089 & .046 & .500 & .016 & .046 & \\
\hline $\mathrm{N}$ & 7 & 7 & 7 & 7 & 7 & 7 \\
\hline
\end{tabular}

Table 2 is the result of data analysis using Bivariate Person obtained rtable with the value of 0.6694 thus, it can be concluded that the overall data items on the questionnaire about the use of puzzle learning media for the solar system material are correlated significantly with the total score. This is because the value of each item x.1 
(the media content are compatible with learning objectives) is 0.673 , item x.2 (learning media is easy to operate) is 0.681 , item x.3 (learning media to increase learning motivation) is 0.781 , item $x .4$ (the learning media used can help in understanding the concepts correctly) is 0.794 , and item $x .5$ (the learning media used can arouse new desires and interests) is 0.681 .

The effectiveness of using puzzle learning media with solar system material in this study was seen by using the pre-test and post-test written test method in the form of matched questions. This test was chosen to make it easier for children with disabilities to work on problems. A summary of the written test result data description can be seen in Table 3.

Table 3. Summary of Research Data Description

\begin{tabular}{|l|l|}
\hline Description & Test Results \\
\hline The average of pre-test score & 14.29 \\
\hline The average of post-test score & 42.86 \\
\hline $\begin{array}{l}\text { The average of score } \\
\text { enhancement }\end{array}$ & 28.57 \\
\hline
\end{tabular}

Table 3 about the summarizes of data description above explaining that the average value of the pre-test before learning using puzzles is 14.29 while the post-test scores after learning are 42.89 so it can be concluded that there is an average increase in value of 28.57. While the T test results for children with disabilities can be seen in table 4.

Table 4. The T test results of pre-test and post-test

Paired Samples Test

\begin{tabular}{|c|c|c|c|c|c|c|c|c|}
\hline & \multicolumn{5}{|c|}{ Paired Differences } & \multirow[b]{3}{*}{$\mathrm{t}$} & \multirow[b]{3}{*}{$\mathrm{df}$} & \multirow[b]{3}{*}{ Sig. (2-tailed) } \\
\hline & \multirow[b]{2}{*}{ Mean } & \multirow[b]{2}{*}{ Std. Deviation } & \multirow{2}{*}{$\begin{array}{c}\text { Std. Error } \\
\text { Mean }\end{array}$} & \multicolumn{2}{|c|}{$\begin{array}{l}95 \% \text { Confidence } \\
\text { Interval of the } \\
\text { Difference }\end{array}$} & & & \\
\hline & & & & Lower & Upper & & & \\
\hline $\begin{array}{ll}\text { Pair } 1 & \text { PRE TEST - POST TEST }\end{array}$ & -28.571 & 10.690 & 4.041 & -38.458 & -18.684 & -7.071 & 6 & .000 \\
\hline
\end{tabular}

According to the table $4 \mathrm{~T}$ test results the pre-test and post-test values obtained sig. $0.000<$ probability 0.05 thus, it can be said that there is a relation between the pretest variable with the post-test variable. The value of $t$ table is 2.447 while $t$ count is 7.071. $\mathrm{T}$ table value $>\mathrm{t}$ arithmetic so that there is an influence of puzzle learning media for children with disabilities. Based on these results it can be seen that there is effectiveness of puzzle media for the learning process of solar system materials for children with disabilities.

According to the the interviews results with the caregivers of disabled children in the Sayap Ibu Nursing Home 2, it can be seen that using puzzles as learning media can help the process of learning solar system material. Children become interested and motivated to get a new learning that they have never had in their daily lives. The observations results on learning activities of solar system material using puzzle also shows how active the children participate in the learning process. They were very enthusiastic to ask questions, play while learn to use puzzle. 
According to the results of tests, observations, documentation and interviews it can be seen that the use of learning media in the form of puzzles has effectiveness in the learning process of solar system material. It is compatible with research conducted by Syahruddin, et al (2017) who said that to explore the potential exists in disabled children it can be done by using models and learning media that are easy, fun, interesting, inexpensive and mass. One example of learning media that can be used is puzzle games. Puzzle game is a game that can improve thinking power as well as eyes and hands coordination. This was also mentioned by Arifin (2015) in which based on the results of his research showed that the use of instructional media that was made effectively, interestingly, and easily to be used is greatly helped the learning process. Learning media can explain physics material that is not visible by the eye becomes easier to understand by using media in the form of images or simple animations.

In addition, research about the effect of puzzles in the learning process has also been conducted by Purwantoko, R. A. (2010). According to these results it can be concluded that the learning process with the use of puzzle can be used as an alternative instructor as one of fun learning methods because puzzle games is able to produce motivation and students' concept acknowledgement better. Besides that, puzzle as learning media makes the learning process be more efficiently than the use of lecture methods in general.

\section{CONCLUSION}

According to the result of this study indicates that the used of puzzle as a learning media has an effectiveness which influences the learning process of solar system. This is indicated by the average difference of the pre-test and post-test values of 28.57 and the results of the $\mathrm{T}$ test which show that $\mathrm{t}$ table> $\mathrm{t}$ count. Based on this it can be concluded that learning media made with interesting and as easy as possible for example is a puzzle game media has the effectiveness to be used in learning.

\section{ACKNOWLEDGEMENTS (OPTIONAL)}

Acknowledgments were given to the research sponsors and resource persons in this study, among others: DRPM Kemenristekdikti, STTKD Yogyakarta, and resource persons, caregivers, and children at Sayap Ibu Yogyakarta Nursing Home.

\section{REFERENCES}

A.T. Setiawan, "Efektivitas Media PIuzzle untuk Meningkatkan Kemampuan Menyusun Kalimat bagi Cerebral Palsy," E-JUPEKhu (Jurnal Ilm. Pendidik. Khusus), vol. 1, no. September, pp. 27-36, 2012. 
Agustina, M., Sesunan, F., \& Ertikanto, C. (2017). Pengaruh Implementasi Media Pembelajaran Interaktif Berbasis Macromedia Flash terhadap Hasil Belajar pada Materi Hukum Newton tentang Gravitasi. Jurnal Pembelajaran Fisika, 5(5).

Arifin, T., Rosidin, U., \& Wahyudi, I. (2015). Pengembangan Media Sains Berbasis Game Edukasi pada Materi Tata Surya. Jurnal Pembelajaran Fisika, 3(2).

Fauzan, M., Gani, A., \& Syukri, M. (2017). Penerapan model problem based learning pada pembelajaran materi sistem tata surya untuk meningkatkan hasil belajar siswa. Jurnal Pendidikan Sains Indonesia, 5(1), 27-35.

Putri, S., \& Markamah, E. (2015). PENINGKATAN KEMAMPUAN MENGENAL BENTUK GEOMETRI MELALUI PERMAINAN PUZZLE PADA ANAK KELOMPOK A TK ISLAM TERPADU AISYIYAH LABAN MOJOLABAN SUKOHARJO TAHUN AJARAN 2014/2015.

R. A. Purwantoko, "Keefektifan Pembelajaran Dengan Menggunakan Media Puzzle Terhadap Pemahaman Ipa Pokok Bahasan Kalor Pada Siswa Smp," J. Pendidik. Fis. Indones., vol. 6, no. 2, pp. 123-127, 2010.

S. Syahruddin, M. S. Saleh, and A. Rizal, "Peningkatan Koordinasi Mata Tangan Melalui Model Pembelajaran Berbasis Bermain Bagi Anak Tuna Grahita," Semin. Nas. Lemb. Penelit. UNM, vol. 2, no. 1, pp. 116-119, 2017.

W. Afifah and S. Hadi, "Pengaturan Hak Pendidikan Disabilitas,” pp. 272-280, 2014. 